\title{
Infliximab treatment time and the mucosal healing effect in pediatric patients with severe Crohn's disease - own experience
}

\author{
Wpływ czasu leczenia infliksymabem na gojenie śluzówki jelita u dzieci z ciężką \\ postacią choroby Leśniowskiego-Crohna - doświadczenia własne
}

\author{
Grażyna Czaja-Bulsa ${ }^{12}$, Aneta Gębala ${ }^{2,3}$, Anna Korlatowicz-Bilar ${ }^{2}$ \\ 1Department of Pediatric Nursing, Pomeranian Medical University, Szczecin, Poland \\ 2Independent Laboratory of Propaedeutics in Paediatrics, Pomeranian Medical University, Szczecin, Poland \\ 3Division of Paediatrics, Gastroenterology and Rheumatology of Zdroje, Hospital, Szczecin, Poland
}

Przegląd Gastroenterologiczny 2012; 7 (2): 87-93

DOI: $10.5114 / p g .2012 .28650$

Key words: Crohn's disease, mucosal healing, infliximab.

Słowa kluczowe: choroba Leśniowskiego-Crohna, gojenie śluzówkowe, infliksymab.

Address for correspondence: Prof. Grażyna Bulsa MD, PhD, Department of Pediatric Nursing, Pomeranian Medical University, 48 Żołnierska, 71-210 Szczecin, Poland, phone: +48 9188060 73, e-mail: grazyna.bulsa@wp.pl

\begin{abstract}
Introduction: Mucosal healing is of vital importance for complete and sustainable clinical remission of Crohn's disease (CD). Aim: To evaluate the effect of the infliximab (IFX) treatment duration on mucosal healing and clinical remission in pediatric patients with severe CD.

Material and methods: The authors analyzed data of 10 children aged 6-18 treated with IFX (5 mg/kg; induction: 0, 2, 6 weeks, continuation: every 4 or 8 weeks). The disease activity (Pediatric Crohn's Disease Activity Index - PCDAl) and mucosal healing (Simple Endoscopic Score for Crohn's Disease - SES-CD) were assessed one month after the $3^{\text {rd }}, 6^{\text {th }}$ and $9^{\text {th }}$ IFX dose. Results: After 3, 6, 9 IFX doses clinical remission (PCDAI $\leq 10$ points) was observed respectively in 5 (50\%), 7 (70\%), 7 (70\%) patients and clinical response (11 points $\leq \mathrm{PCDAI} \leq 30$ points) in $2(20 \%), 2(20 \%)$ and $1(10 \%)$ patients. Endoscopic remission (SES-CD) was seen respectively in $1(10 \%), 2$ (20\%) and 4 (40\%) patients.

Conclusions: In the majority of children with severe CD not responding to conventional treatment the biological IFX treatment induces clinical remission. Prolonged treatment with IFX increases the number of remissions. During the IFX therapy clinical response is observed significantly earlier than mucosal healing. Continuation of the therapy in children with positive clinical response to IFX enhances further mucosal healing and allows steroids to be discontinued. In patients who lose response to the IFX therapy during the maintenance treatment the therapeutic effect can be restored by shortening intervals between doses or by doubling the dose.
\end{abstract}

\section{Streszczenie}

Wstęp: Wygojenie śluzówki jelita jest niezwykle istotne dla pełnej i długotrwałej remisji klinicznej w przebiegu choroby Leśniowskiego-Crohna (ChLC).

Cel: Ocena wpływu czasu leczenia infliksymabem (IFX) na gojenie śluzówki jelita i remisję kliniczną u dzieci z ciężką postacią ChLC.

Materiat i metody: Analizowano dane 10 dzieci w wieku 6-18 lat leczonych IFX (5 mg/kg m.c.; indukcja remisji: 0, 2, 6 tygodni, kontynuacja: co 4 lub 8 tygodni). Aktywność choroby (Pediatric Crohn's Disease Activity Index - PCDAl) i gojenie śluzówkowe (Simple Endoscopic Score for Crohn's Disease SES-CD) oceniano miesiąc po 3., 6. i 9. dawce IFX.

Wyniki: Po 3, 6 i 9 dawkach IFX remisję kliniczną (PCDAI $\leq 10$ pkt) uzyskano odpowiednio u 5 (50\%), 7 (70\%) i 7 (70\%) pacjentów, a odpowiedź kliniczną (11 pkt $\leq$ PCDAl $\leq 30$ pkt) u 2 (20\%), 2 (20\%) i 1 (10\%). Remisję endoskopową (SES-CD) obserwowano odpowiednio u 1 (10\%), 2 (20\%) i 4 (40\%) pacjentów.

Wnioski: U większości dzieci z ciężką postacią ChLC, nieodpowiadających na leczenie konwencjonalne, terapia biologiczna IFX indukuje remisję kliniczną. Przedłużone leczenie IFX zwiększa odsetek remisji. Podczas terapii tym lekiem remisja kliniczna znacznie wyprzedza proces gojenia śluzówkowego. Kontynuacja leczenia u dzieci z pozytywną reakcją kliniczną na IFX wptywa korzystnie na dalszy proces gojenia śluzówkowego i umożliwia odstawienie glikokortykosteroidów. U pacjentów, którzy w trakcie terapii podtrzymującej przestają odpowiadać na leczenie IFX, zmniejszenie odstępów między dawkami lub podwojenie dawki może przywrócić efekt terapeutyczny. 


\section{Introduction}

Progress in the studies on pathophysiology of nonspecific inflammatory bowel disease (IBD) and the use in IBD treatment of modern biological substances that neutralize the reaction to tumour necrosis factor $\alpha$ (TNF- $\alpha$ ) have allowed new therapeutic goals to be set.

Until now conventional treatment was administered mainly to fight symptoms of the disease. Biological drugs, which are the most powerful known activators of mucosal healing, give hope for modification of the natural course of the disease. Recently published study results concerning IBD treatment have introduced the term of socalled deep remission as the most desired therapeutic effect. Deep remission is defined by the absence of the disease symptoms and by mucosal healing in the form of complete absence of ulcers. Mucosal lesions resulting from chronic inflammation cause such complications as stenosis, fistulas and migration of pathogenic bacteria to pus cisterns, perforations and neoplasia related to the basic disease. The therapeutic effect in the form of healing of micro and macro mucosal lesions leads to improvement and to clinical remission. What is more, if introduced soon enough (in the inflammatory phase), it reduces the risk of complications or related surgery and long hospitalization. Nowadays mucosal healing, in Crohn disease (CD) preferably of the intramural mucosa, is the only chance for a milder course of the disease. The existing observations indicate clearly the relation between healed mucosa and prolonged remission [1-4].

In the era of conventional medicine such an effect was rarely achieved, especially in patients with severe and moderately severe form of the disease. Steroids used in IBD therapy do not heal mucosa and therefore have been administered neither to sustain remission nor to prevent post-resection relapse [5]. Because it is impossible to modify the inflammation process in mucosa itself, the disease reoccurs in many patients who have been treated with steroids in the acute phase although their initial clinical response to therapy was satisfactory. Purine analogues (azathioprine - AZT, 6-mercaptopurine - 6MP) and methotrexate (MTX) have mucosal healing properties and can induce endoscopic and histological (usually partial) remission $[6,7]$. The absence of full mucosal remission, especially in MTX maintenance treatment, may be responsible for frequent relapse of the disease. An additional limitation to early mucosal healing by means of immunomodulators is their delayed activity and complications in the form of myelosuppression and opportunistic infections. So far the observations have not provided evidence that a natural course of the disease can be modified by immunomodulation therapy. However, very quick clinical remission and mucosal regeneration was observed after administration of the biological substances anti-TNF- $\alpha$. The first and most thoroughly tested drug belonging to this group is infliximab (IFX), whose effectiveness is independent of the inflammation severity and location [8]. The effect of prolonged IFX therapy on mucosal regeneration has been demonstrated in many reports [9].

Nonetheless, biological drugs are still being tested. It is known that although the effects of biological therapy are very promising (particularly at the beginning of the treatment), it is not a remedy for all patients. In the longer term the effects are less spectacular and the patients require larger doses or the infusions need to be more frequent. And, similarly to steroid dependency, the new term of anti-TNF- $\alpha$ dependency has appeared [10]. The questions still debated are: how to select patients to be treated with biological drugs; how long and intensive the therapy should be; which other immunosuppressive drugs it should be combined with; if endoscopic control is necessary and how often it should be done; and finally, if the biological treatment is safe. Children are a specific group of patients who require thorough and independent tests in many research centers because of fewer observations carried out in pediatric centers, long-term disease perspectives as well as the effect of its course and related treatment on young patients' growth.

\section{Aim}

In the study we present our center's first experiences with biological therapy administered to children with severe $C D$, with special attention paid to the influence of the IFX therapy duration on the occurrence and maintenance of disease clinical remission and on mucosal healing.

\section{Material and methods}

In the study we analyzed data of 10 children who have been treated with IFX since 2007. The study was of a prospective character. The children were qualified for biological therapy due to the severity of their illness (Pediatric Crohn's Disease Activity Index - PCDAI > 51 points) as well as due to the lack of response to conventional treatment with corticosteroids and immunosuppressants.

The IFX was administered in a dosage of $5 \mathrm{mg} / \mathrm{kg}$ of body mass in the scheme of $0,2,6$ weeks in order to induce remission, and then every 8 weeks to maintain it. Patients with incomplete response to therapy or who ceased to respond in its course received the dosage of $10 \mathrm{mg} / \mathrm{kg}$ of body mass or their time between IFX infusions was shortened to 4 weeks (Table I). 
Table I. Characteristics of patients with Crohn's disease treated with IFX

Tabela I. Charakterystyka pacjentów z chorobą Leśniowskiego-Crohna leczonych IFX

\begin{tabular}{|c|c|c|c|c|c|c|c|c|c|c|}
\hline \multirow{2}{*}{$\begin{array}{l}\text { Sex/age [years] } \\
\text { M/12.5 }\end{array}$} & \multirow{2}{*}{$\begin{array}{l}\text { Paris classification } \\
\text { A1bL2B1 }\end{array}$} & \multirow{2}{*}{$\begin{array}{c}\begin{array}{c}\text { Disease duration } \\
\text { before IFX } \\
\text { treatment [months] }\end{array} \\
3\end{array}$} & \multicolumn{4}{|c|}{$\begin{array}{l}\text { PCDAI - before treatment } \\
- \text { after } 3^{\text {rd }}, 6^{\text {th }} \text { and } 9^{\text {th }} \text { IFX }\end{array}$} & \multicolumn{4}{|c|}{$\begin{array}{l}\text { SES-CD - before treatment } \\
\text { - after } 3^{\text {rd }}, 6^{\text {th }} \text { and } 9^{\text {th }} \text { IFX }\end{array}$} \\
\hline & & & 90.5 & 17.5 & 10.0 & 10.0 & 15 & 15 & 7 & 1 \\
\hline$F / 16.0$ & A1bL2B1 & 6 & 67.5 & 20.0 & 20.0 & 0.0 & 10 & 0 & 0 & 1 \\
\hline$M / 18.0$ & A2L2B1 & 15 & 62.5 & $50.0^{*}$ & 57.5 & 65.0 & $18 \mathrm{r}$ & $18_{r}^{*}$ & $18_{r}\left(34_{c}\right)$ & $32_{c}$ \\
\hline$F / 13.5$ & A1bL2B1 & 3 & 62.5 & $42.5^{*}$ & 10.0 & 0.0 & 14 & $26^{\star}$ & 17 & - \\
\hline$M / 12.0$ & A1bL3B2 & 29 & 52.5 & $25.0^{*}$ & 27.5 & 47.5 & 17 & $20^{*}$ & 24 & 21 \\
\hline$F / 7.0$ & A1aL3B1 & 14 & 52.5 & $7.5^{\star}$ & 7.5 & 22.5 & 3 & $10^{*}$ & 5 & 5 \\
\hline$M / 13.5$ & A1bL3L4aB1 & 6 & 52.5 & 5.0 & 0.0 & 0.0 & 24 & 16 & 7 & 7 \\
\hline$M / 13.5$ & A1bL2B1 & 33 & 52.5 & 5.0 & 0.0 & 0.0 & 4 & 11 & 0 & 1 \\
\hline$M / 15.5$ & A1bL2B1 & 3 & 52.0 & 0.0 & 0.0 & 0.0 & 24 & 16 & 7 & 6 \\
\hline M/15.0 & A1bL3B1 & 29 & 51.0 & 0.0 & 0.0 & 0.0 & 10 & 10 & 9 & 1 \\
\hline Average & $\begin{array}{c}\text { A1bL2B1-5 } \\
\text { A1bL3B1-3 } \\
\text { A2L2B1-1 } \\
\text { A1bL3L4aB1-1 }\end{array}$ & 14.1 & 59.6 & 17.25 & 13.25 & 14.5 & 13.9 & 14.2 & 9.4 & 7.5 \\
\hline
\end{tabular}

$r$-rectosigmoidoscopy, c-colonoscopy; ${ }^{*} 10 \mathrm{mg} / \mathrm{kg}$ of body mass or time between IFX was shortened to 4 weeks

Crohn's disease was diagnosed by means of the Porto criteria and characterized according to the Paris classification [11]. The analysis takes into consideration the patients' age and sex, the disease duration before treatment, the location of inflammatory lesions, the disease complications, other immunosuppressive treatments and the adverse effects of administered drugs.

The main subject of the study was clinical and endoscopic activity of the disease before and during the IFX therapy. The activity of the disease was evaluated on the basis of clinical and biochemical criteria according to the PCDAI scale - before the introduction of the biological treatment, and 4 weeks after the $3^{\text {rd }}, 6^{\text {th }}$ and $9^{\text {th }}$ dose of IFX [12]. Clinical remission was defined as PCDAI $\leq 10$ points, clinical response as 11 points $\leq$ PCDAI $\leq 30$ points.

Full colonoscopy with a terminal ileum evaluation and an upper tract endoscopy with tissue sampling was performed at the beginning of the treatment, 4 weeks after induction therapy, and 4 weeks after the $6^{\text {th }}$ and $9^{\text {th }}$ dose of IFX. Additionally an ultrasound scan of the abdominal cavity and the gastrointestinal passage was performed. Selected patients were subjected to computed tomography $(\mathrm{CT})$ enteroclysis in order to find the exact location of the disease.

Intensification of inflammatory lesions on endoscopy was assessed according to the CD endoscopic index of severity Simple Endoscopic Score for Crohn's Disease (SES-CD), with a particular focus on the presence of ulcers [13]. The criterion for full mucosal healing was complete absence of ulcers; for partial mucosal healing it was visible reduction of inflammatory lesions demonstrated by a low SES-CD score while ulcers were still present. Mucosal healing failure was reflected by an unchanged or worsened endoscopic picture. The SES-CD scores were calculated immediately after a colon endoscopy. As the other authors' studies have shown, the CD severity assessed by means of the simplified SES-CD score corresponds to the results of assessment performed by means of a full endoscopic evaluation.

\section{Results}

The characteristics of patients and the treatment results are presented in Table I and in Figures 1-2. After 3 IFX doses clinical remission was observed in 5 patients (50\%) and clinical response in 2 (20\%). In 3 children (30\%) pathological signs had stabilized, their general feeling and biochemical test results had improved but the criteria of clinical response were not fulfilled. After $6 \mathrm{IFX}$ doses clinical remission was observed in 2 other patients; thus the number of remissions amounted to $70 \%$. Clinical response was achieved in 2 children (20\%) while 1 child (10\%) did not respond to the therapy. After 9 doses clinical remission was maintained in 7 patients (70\%), 1 child met the criteria of a clinical response, and in 2 patients high activity of the disease was observed.

Following 3 IFX doses in 4 patients (40\%) partial mucosal healing and a lower SES-CD score were observed. Full endoscopic and histological remission was observed in one girl only. After 6 IFX doses in 2 chil- 


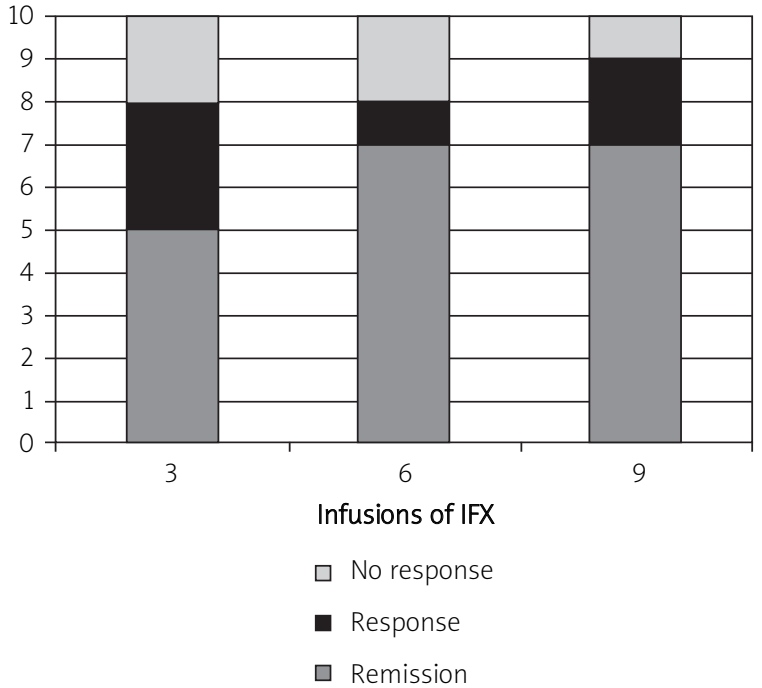

Fig. 1. Clinical response after 9 infusions of IFX (3 induce remission doses and 6 maintenance doses) in pediatric patients with severe $C D$ (remission: PCDAl < 10 points, response: $11<$ PCDAI < 30 points)

Ryc. 1. Odpowiedź kliniczna po 9 dawkach IFX (3 dawki indukujące remisję i 6 dawek podtrzymujących) u dzieci z ciężka choroba Leśniowskiego-Crohna (remisja: PCDAl < 10 pkt, odpowiedź: $11<P C D A l<30$ pkt)

dren $(20 \%)$ mucosa was fully healed, in $4(40 \%)$ the healing was partial, while in the other $4(40 \%)$ no mucosal healing was observed. After 9 IFX doses 4 (40\%) patients demonstrated endoscopic remission, in 3 (30\%) a stationary picture of minor inflammatory lesions could be seen, in $2(20 \%)$ the inflammatory lesions were still active, while 1 child was withdrawn from the study.

The authors also analyzed the relation between improved clinical signs and the extent of mucosal healing in the course of the IFX treatment. Out of 5 patients who experienced remission after 3 IFX doses, in none was endoscopic remission observed, in 4 patients partial mucosal healing had taken place, while in one of them the lesions remained unaltered. One girl with full mucosal remission met the requirements of clinical response only due to her body mass deficit. She had anorexia nervosa too. In a group of 7 patients with clinical remission after 6 IFX doses only one had endoscopic remission, 4 displayed partial mucosal healing and two patients did not experience any improvement in the endoscopic image. Following 9 IFX doses clinical remission was maintained in 7 patients ( 3 of them displaying

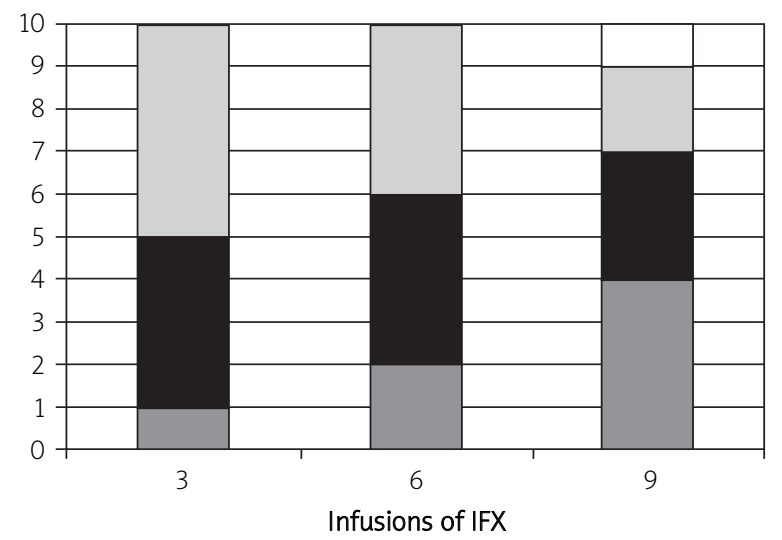
$\square$ No-colonoscopy
$\square$ No-response
- Reduction of inflammatory lesions
- Absence of ulcers

Fig. 2. Mucosal healing after 9 infusions of IFX (3 induce remission doses and 6 maintenance) in pediatric patients with severe CD. Intensification of inflammatory lesion were assessed according to the endoscopic index of severity SES-CD

Ryc. 2. Gojenie śluzówkowe po 9 dawkach IFX (3 dawki indukujące remisję i 6 dawek podtrzymujących) u dzieci z ciężka chorobą Leśniowskiego-Crohna. Nasilenie zapalenia byto określane zgodnie z endoskopowym indeksem ciężkości SES-CD

mucosal remission as well), while in the others partial mucosal healing could be observed.

After 12 months of treatment (9 IFX doses) two children displayed intensified clinical CD symptoms (increased PCDAI) with inflammatory lesions in their mucosa more severe than at the start of the treatment. In both of those patients clinical remission had been achieved by doubling the IFX doses. When the doses were reduced, the CD symptoms intensified (Table I).

The majority of children received oral prednisone (5-10 mg). All of them were simultaneously given AZT or MTX immunomodulators.

In short observation, biological treatment was safe. Complications were of a mild nature and were easy to treat: in 2 patients herpes zoster infection took place and during the infusion general symptoms were observed; 1 boy developed pneumonia.

\section{Discussion}

The IFX is an effective medicine which helps to induce and maintain remission, which has been proved in the course of many clinical studies. Unfortunately it is 
difficult to compare the results of individual studies because they cover patients of different age, disease duration and activity, concomitant drugs as well as varying biological treatment schemes. Even fewer observations concern children since they became the subject of biological treatment later and it was not until recently that this kind of therapy has been made available for patients with severe CD.

Despite the increased incidence of $C D$ this group of patients is rather small and the scarce independent multi-center studies do not allow objective conclusions to be drawn concerning the application of biological treatment in children. What is more, the observations carried out in adult populations cannot be of use, since a different genotype and phenotype as well as the role that immunological factors play in the youngest patients can affect the clinical response.

In our test group $80 \%$ of patients responded to IFX therapy. After induction treatment with 3 IFX doses remission was observed in half of them, and after 6 and 9 doses in $70 \%$ of children. Clinical response occurred significantly earlier than endoscopic remission (complete mucosal healing). All the children had severe CD with a high PCDAl score and that is why biological treatment was administered in combination with immunomodulators and, in the majority of patients, with small doses of steroids.

Until now few multi-center randomized studies have been published that would allow one to form an objective opinion concerning the effectiveness, safety and optimum dosage of biological drugs in children. Initially, the publications presented the results of treatment with only one dose of IFX. Early, but often transient, remission was observed in almost $50 \%$ of patients. Their number quickly decreased, however, when therapy was not continued. Better clinical effect was also associated with short disease duration of $1-2$ years $[14,15]$, but that conclusion was later questioned when further studies were carried out in a larger population of children [16]. Another large research project was REACH, a prospective, multi-center, randomized study based on the analysis of therapy results in 112 children with moderately severe and severe CD. It proved the effectiveness of IFX in inducing and maintaining disease remission [17]. In the $10^{\text {th }}$ week of therapy, after 3 IFX doses, clinical response was achieved in $88.4 \%$ of patients and clinical remission in $58.9 \%$. Such results were similar to those obtained in our center, despite the fact that in the REACH study patients suffered from both severe and moderately severe (PCDAl > 30) CD, which could result in slightly better therapy effects. Even more promising results of applying the therapy in children have been published in the last two years. In French studies
Wynands et al. [18] observed clinical remission in the $3^{\text {rd }}$ month of therapy, after 3 IFX doses in 36 of 38 treated children (95\%). Ruemmele et al. [9] described such clinical effect as a result of induction therapy in $85 \%$ of patients. But to maintain remission the majority of children had to continue treatment, often with modified dosage and intervals between doses in patients with a particularly active form of the disease.

Studies on adult populations with $C D$ are more numerous and they also confirm the positive effects of biological therapy. In one recent research project, GETAID, $75 \%$ of patients with steroid-dependent CD obtained clinical remission after 12 weeks of IFX therapy combined with AZT, without steroids [19].

Our findings show that the absence of clinical remission after 3 doses of IFX does not suggest primary resistance to IFX and prolonged treatment often results in remission. In our material 2 children (20\%) initially only showed a clinical response to the drug and it was not until the $6^{\text {th }}$ IFX dose had been administered to them that remission took place. The administration of further IFX doses did not increase the number of patients demonstrating clinical remission. Another controversial issue is individual IFX dosage designed for each patient. As some studies have shown, the number of remissions is strongly correlated with the concentration of the drug in serum and increases together with its growth [20]. In our center we are not able to determine IFX concentration, but we observed that two of our patients responded positively to the drug when the dose had been doubled. We do not know if it was the effect of individual metabolism of the drug or if it was conditioned by other factors. Another problem occurring in the process of biological therapy is the fact that frequently it is necessary to intensify and prolong the treatment $[18,21]$. This concerns about $50 \%$ of patients, typically after 12 months of therapy, but it can happen earlier. Most patients respond to the IFX dosage being increased to $10-15 \mathrm{mg} / \mathrm{kg}$ or to the intervals between the doses being shortened from 8 to 4 weeks. Four of our patients (40\%) were treated with a doubled dose. Until now statistically significant risk factors predisposing to a failed response to the standard IFX dosage have not been identified. An important mechanism responsible for a weakened reaction to the drug and to an acute post-transfusion reaction may be the process of IFX antibody production [22]. Some studies suggest that regular drug intake and the administration of immunomodulators can limit their synthesis, but other sources do not confirm such a relationship [21-25]. Due to the severity of illness our patients received IFX therapy combined with AZT or MTX. Despite such a regime, the percentage of patients who required early intensifi- 
cation of treatment remained high (40\%). Some studies on adults suggest that combined IFX and AZT treatments increase a patient's chance for remission [26]. It seems essential to confirm that observation in a larger group of children and to determine the advantage of such treatment over IFX monotherapy. It is particularly important in view of reports about the increased risk of T-cell liver lymphoma in young men receiving IFX therapy combined with AZT [27].

An increasing number of reports point to a vital role of mucosal healing as analogous to deep disease remission that makes it possible to change the illness natural course and thus reduce the progression of inflammatory lesions, complications, hospitalization and surgical interventions [1-3].

Such a correlation is not typical only of IFX, but this particular drug is thought to be one of the most effective medicines as far as intestinal mucosa regeneration is concerned.

In the light of these observations the endoscopic assessment of mucosal healing is crucial to verify the CD treatment effectiveness.

In spite of the important correlation between the severity of pathological changes found and measured by means of endoscopy and the clinical activity of the disease, in many patients the remission of symptoms significantly precedes the endoscopic and, specifically, the histological remission. We have confirmed such correlation in our patients as well. Only one girl demonstrated quick clinical improvement simultaneously with endoscopic and histological remission after administration of 3 IFX doses. The number of children with full endoscopic remission increased most between the $6^{\text {th }}$ and the $9^{\text {th }}$ IFX dose. The fact that clinical signs may not be correlated with endoscopic changes and that the mucosal healing effect can be absent or significantly delayed in relation to the regression of clinical signs was confirmed by the total failure of mucosal healing in one of our patients who had demonstrated clinical remission after the induction treatment. In other patients in whom clinical remission had been diagnosed earlier, further shrinking of the lesion was observed after successive IFX doses. This fact proves the limited value of the PCDAl in assessing IFX effectiveness when treating mucosal ulceration. The observations by other authors show that the discontinuation of treatment in the clinical remission phase, but without full recovery of the mucosa, can be an important factor signaling quick relapse and aggravation of the disease [28]. On the other hand, mucosal remission gives a better opportunity for long-term clinical remission and reduces the number of permanent complications [1-3].
These observations indicate that it is necessary to continue biological treatment even after clinical remission as well as to continue endoscopic scanning at the subsequent stages of therapy. Therefore it is important to define the optimum span of time for control endoscopy to be carried out in children subjected to biological therapy.

Schnitzler et al. [4] analyzed endoscopic pictures of 214 adult patients who had received 3 IFX doses and who were on average 6.7 months after the treatment initiation, and they observed mucosal healing in $68 \%$ of them. Complete mucosal healing was observed in $45.4 \%$, while partial mucosal healing was observed in $22.4 \%$. Such a therapeutic effect, particularly when maintenance treatment was continued, yielded longterm remission and significant reduction in indications for hospitalization and surgical interventions.

According to the latest research, the most effective treatment in adults is early biological therapy in combination with immunosuppressants administered in a topdown scheme (3 doses of infliximab and AZT). Such treatment results in quick resolution of clinical signs and leads to mucosal healing. D'Haens et al. [29] described intestinal mucosa free of ulcerations and meeting the healing criteria in over $73 \%$ of patients treated according to that scheme and undergoing endoscopic control in the second year of therapy.

Unfortunately, some patients who have demonstrated the desired effect of so-called deep remission in the longer term suffer from further episodes of aggravation of the disease characterized by a course and location similar to those diagnosed prior to the biological treatment. Thus the basic pathomechanism of the inflammatory process is not permanently blocked by biological drugs, which makes expectations to modify the natural disease course less optimistic.

Another important aspect of the research into biological therapy is to evaluate its short and long-term safety. We have not observed in our patients any severe adverse effects that would make termination of the therapy necessary. The mild complications mentioned above were similar to those described in other authors' reports. Unfortunately, the number of children suffering from CD treated with IFX as well as the observation time has been insufficient to decide if the therapy is safe. Incidents of T-cell liver lymphoma in young patients and other possible effects of deep immunosuppression caused by IFX therapy show that we should be careful when drawing conclusions.

\section{Conclusions}

In most children with severe $C D$ who were nonresponsive to conventional treatment, biological IFX 
therapy induces clinical remission. Prolonging the IFX treatment increases the number of remissions. During the IFX therapy clinical remission significantly precedes mucosal healing. Continuation of the therapy in children displaying positive clinical response to IFX has a positive effect on further mucosal healing and makes it possible to discontinue steroids. In patients who lose response to IFX therapy during maintenance treatment the therapeutic effect can be restored by shortening intervals between doses or by doubling the dose.

\section{References}

1. Fidder HH, Hommes DW. Anti-TNF and Crohn's disease: when should we start? Curr Drug Targets 2010; 11: 143-7.

2. Pineton de Chambrun G, Peyrin-Biroulet L, Lemann M, et al. Clinical implication of mucosal healing for the management of IBD. Curr Drug Targets 2010; 11: 227-33.

3. Rutgeerts P, Vermeire S, Van Assche G. Mucosal healing in inflammatory bowel disease: impossible ideal or therapeutic target? Gut 2007; 56: 453-5.

4. Schnitzler F, Fidder H, Ferrante $M$, et al. Mucosal healing predicts long-term outcome of maintance therapy with infiximab in Crohn's disease. Inflamm Bowel Dis 2009; 15: 1295-301.

5. Modigliani R, Mary JY, Simon JF, et al. Clinical, biological, and endoscopic picture of attaks of Crohn's disease. Evolution on prednisolone. Groupe d'Etude Therapeutique des Affections Inflammatoires Digestives. Gastroenterology 1990; 98: 811-8.

6. D'Haens G, Geboes K, Rutgeerts P. Endoscopic and histologic healing of Crohn's (ileo-) colitis with azathioprine. Gastrointest Endosc 1999; 50: 667-71.

7. Kozarek RA, Patterson DJ, Gelfand MD, et al. Methotrexate induces clinical and histological remission in patients with refractory inflammatory bowel disease. Ann Int Med 1989; 110: 353-6.

8. D'Haens G, Van Deventer S, Van Hogezand R, et al. Endoscopic and histological healing with infliximab anti-tumor necrosis factor antibodies in Crohn's disease: a European multicenter trial. Gastroenterology 1999; 116: 1029-34.

9. Ruemmele FM, Lachaux A, Cezard JP, et al. Efficacy of infliximab in pediatric Crohn's disease: a randomized multicenter open-label trial comparing scheduled to on demand maintenance therapy. Inflamm Bowel Dis 2009; 15: 388-94.

10. Wewer V, Riis L, Vind I, et al. Infliximab dependency in a national cohort of children with Crohn's disease. J Pediatr Gastroenterol Nutr 2006; 42: 40-5.

11. Levin A, Griffiths A, Markowitz J, et al. Pediatric modification of the Montreal classification for inflammatory bowel disease: the Paris classification. Inflamm Bowel Dis 2011; 17: 1314-21.

12. Hyams JS, Ferry GD, Mandel FS, et al. Development and validation of a pediatric Crohn's disease activity index. J Pediatr Gastroenterol Nutr 1991; 12: 439-47.

13. Daperno M, D'Haens G, Van Assche G, et al. Development and validation of a new, simplified endoscopic activity score for Crohn's disease: the SES-CD. Gastrointest Endosc 2004; 60: 505-12.

14. Kugathasan S, Werlin SL, Martinez A, et al. Prolonged duration of response to infliximab in early but not late pediatric Crohn's disease. Am J Gastroenterol 2000; 95: 3189-94.
15. Lionetti P, Bronzini F, Salvestrini C, et al. Response to inflixi$\mathrm{mab}$ is related to disease duration in paediatric Crohn's disease. Aliment Pharmacol Ther 2003; 18: 425-31.

16. Cezard JP, Nouaili N, Talbotec C, et al. A prospective study of the efficacy and tolerance of a chimeric antibody to TNF (Remicade) in severe pediatric Crohn disease. J Pediatr Gastroenterol Nutr 2003; 36: 632-6.

17. Hyams JS, Crandall W, Kugathasan S, et al. Induction and maintenance infliximab therapy for the treatment of moderate-tosevere Crohn's disease in children. Gastroenterology 2007; 132: 863-73.

18. Wynands J, Belbouab R, Candon S, et al. 12-month follow-up after successful infliximab therapy in pediatric Crohn disease. J Pediatr Gastroenterol Nutr 2008; 46: 293-8.

19. Lemann M, Mary JY, Duclos B, et al. Infliximab plus azathioprine for steroid-dependent Crohn's disease patients: a randomized placebo-controlled trial. Gastroenterology 2006; 130: 1054-61.

20. Karmiris K, Paintaud G, Noman M, et al. Influence of trough serum levels and immunogenicity on long-term outcome of adalimumab therapy in Crohn's disease. Gastroenterology 2009; 137: 1628-40.

21. Regueiro M, Siemanowski B, Kip KE, et al. Infliximab dose intensification in Crohn's disease. Inflamm Bowel Dis 2007; 13: 1093-9.

22. Reinisch W. "How to manage loss of response to anti-TNF in Crohn's disease?" Expert Rev Pharmacoecon Outcomes Res 2010; 10: 163-75.

23. Baert F, Noman $M$, Vermeire $S$, et al. Influence of immunogenicity on the long-term efficacy of infliximab in Crohn's disease. N Engl J Med 2003; 348: 601-8.

24. Hanauer SB, Wagner CL, Bala M, et al. Incidence and importance of antibody responses to infliximab after maintenance or episodic treatment in Crohn's disease. Clin Gastroenterol Hepatol 2004; 2: 542-53.

25. Kinney T, Rawlins M, Kozarek R, et al. Immunomodulators and "on demand" therapy with infliximab in Crohn's disease: clinical experience with 400 infusions. Am J Gastroenterol 2003; 98: 608-12.

26. Colombel JF, Sandborn WJ, Reinisch W, et al. Infliximab, azathioprine, or combination therapy for Crohn's disease. N Engl J Med 2010; 362: 1383-95.

27. Mackey AC, Green L, Liang L, et al. Hepatosplenic T cell lymphoma associated with infliximab use in young patients treated for inflammatory bowel disease. J Pediatr Gastroenterol Nutr 2007; 44: 265-7.

28. Arnott ID, Watts D, Ghosh S. Review article: is clinical remission the optimum therapeutic goal in the treatment of Crohn's disease? Aliment Pharmacol Ther 2002; 16: 857-67.

29. D'Haens G, Baert F, Van Assche G, et al. Early combined immunosuppression or conventional management in patients with newly diagnosed Crohn's disease: an open randomised trial. Lancet 2008; 371: 660-7. 